We excluded 57 minor fractures and one haemarthrosis from further analysis as they could be argued to be more serious injuries. We analysed attendance for the remaining 364 case-control pairs only.

Case children attended significantly fewer half days in school after injury than control children (7.38 v 9.40, $\mathrm{P}<0.001)$. Deprivation scores for matched pairs did not differ significantly, and there was no association between missed time at school and deprivation score. Mean half day attendance in the week preceding injury did not differ significantly between case children and control children $(9.25 v 9.59, \mathrm{P}>0.1)$.

\section{Comment}

On average, one full school day was missed unnecessarily after children presented to hospital emergency departments with minor injuries. As children with and without injuries had similar previous school attendance, the resulting loss could be attributed to the injury. The cumulative loss was great given the high frequency of such injuries. Repeated absences of this type could contribute to educational difficulties, especially in children whose attendance is already suboptimal for other reasons.

We propose that health professionals are more proactive in stressing the importance of children attending school after minor injury when there is no medical reason to prevent attendance. Improved liaison between emergency departments, school health services, and local education authorities might help to reduce the unnecessary burden of minor injury.

We are grateful for the valuable assistance of the emergency department staff, all participating schools, and Mrs Lisa Webb for her secretarial help.

Contributors: MM had the original idea for the study and, together with PN, facilitated the collection of data in the accident and emergency departments and drew up definitions for minor injury. AM facilitated the interagency and interdepartmental working, liaised with the education authority, submitted the application to the ethics committee, and is guarantor for the study. PB and LP designed the data collection form, collected the data, established the database, liased with individual schools, and input the data. RL advised on the research method, provided statistical advice, and analysed the data. The paper was written jointly by all authors.

Funding: None.

Competing interests: None declared.

1 Klerman LV. School absence-a health perspective. Pediatr Clin North Am 1988;35:1253-69.

2 Lyons RA, Lo SV, Heaven M, Littlepage BNC. Injury surveillance in children-usefulness of a centralised database of accident and emergency attendances. Inj Prev 1995;1:173-6.

3 Townsend P, Phillimore P, Beattie A. Health and deprivation: inequality and the north. London: Croom Helm, 1998.

(Accepted 11 July 2001)

\title{
Social deprivation in Duchenne muscular dystrophy: population based study
}

\author{
Kate Bushby, Simon Raybould, Sara O'Donnell, James G Steele
}

Duchenne muscular dystrophy is an X linked disorder affecting approximately 1 in 3500 male live births. The incidence remains stable in most populations, maintained by a high rate of new mutations in the dystrophin gene. ${ }^{1}$ We observed that a higher than expected proportion of families of patients with Duchdeprived background, even at the time of first diagnosis (usually by age 5). We measured the level of material deprivation based on the place of residence at the time of diagnosis of all patients with Duchenne muscular dystrophy in the north of England to test the hypothesis that this single gene disorder is associated with social deprivation. enne muscular dystrophy seemed to be from a

\section{Participants, methods, and results}

Records of children with Duchenne muscular dystrophy in the Northern region of England have been scrupulously maintained since the 1960s, and we believe that ascertainment in the region is complete. We analysed data from the whole group of families with Duchenne muscular dystrophy in the region and also subdivided the group into four categories according to the origin of the mutation in the family (table).

In all, 229 of the 246 families with children diagnosed as having Duchenne muscular dystrophy between 1967 and 1999 in the Northern region had valid postcodes available at diagnosis. We linked

Townsend scores of enumeration districts with and without families with Duchenne muscular dystrophy

\begin{tabular}{|c|c|c|c|c|c|c|c|}
\hline \multirow[b]{2}{*}{ Group } & \multicolumn{4}{|c|}{ Duchenne muscular dystrophy } & \multicolumn{2}{|c|}{$\begin{array}{l}\text { No Duchenne muscular } \\
\text { dystrophy ( } n=6624)\end{array}$} & \multirow[b]{2}{*}{ Significance } \\
\hline & No & Median & Range & $\begin{array}{l}\text { Interquartile } \\
\text { range }\end{array}$ & Median & $\begin{array}{l}\text { Interquartile } \\
\text { range }\end{array}$ & \\
\hline All cases & 229 & 3.44 & -5.74 to 10.12 & 0.34 to 5.45 & 1.46 & -2.04 to 4.74 & $P<0.0001$ \\
\hline History in earlier generation & 42 & 3.15 & -5.74 to 10.12 & 0.65 to 5.05 & 1.46 & -2.04 to 4.74 & $P<0.0001$ \\
\hline New mutation in mother & 62 & 4.45 & -4.71 to 9.59 & 1.76 to 5.63 & 1.46 & -2.04 to 4.74 & $P<0.0001$ \\
\hline New mutation in child & 40 & 2.63 & -5.66 to 8.46 & -0.38 to 4.96 & 1.46 & -2.04 to 4.74 & $P=0.001$ \\
\hline No earlier history: mutation origin unknown & 85 & 3.35 & -2.63 to 7.41 & -1.87 to 5.36 & 1.46 & -2.04 to 4.74 & $\mathrm{P}<0.0001$ \\
\hline
\end{tabular}

Institute of Human
Genetics,
International
Centre for Life,
Newcastle upon
Tyne NE1 3BZ
Kate Bushby
professor of
neuromuscular
genetics methods are on the BMJ's website 
Medical School, University of Newcastle upon Tyne, Newcastle upon Tyne NE2 4BW Sara O'Donnell medical student

Department of Restorative Dentistry, University of Newcastle upon Tyne, Newcastle upon Tyne NE2 4BW James G Steele senior lecturer

Correspondence to: K Bushby kate.bushby@ncl. ac.uk patients' postcodes to data from the latest national census by using the central postcode directory, which provides a link between postcodes and enumeration districts consisting of 100-150 households. No enumeration district contained more than one affected family, and each family was counted as a single case irrespective of the number of boys affected.

We used a non-parametric test (Mann-Whitney U test) to compare the Townsend scores ${ }^{2}$ for enumeration districts in which cases of Duchenne muscular dystrophy occurred against all enumeration districts in the region without cases, for all cases and for the four subgroups. We then used Monte Carlo analysis to compare the mean and distribution of scores for the enumeration districts of all affected families with the distribution of Townsend scores derived from repeated random samples of enumeration districts.

The results (table) show large and significant differences between the Townsend scores of affected families and Townsend score distributions for the rest of the population (corrected for the number of children aged 5 and under). The differences occurred in all of the subgroups. The Monte Carlo analysis confirmed the difference between affected families and the rest of the population-the mean Townsend score for the affected boys was at least 2.5 standard deviations greater than that for the random control groups in every iteration.

\section{Comment}

As a group, patients with Duchenne muscular dystrophy have significantly greater material deprivation at diagnosis than the average of the population from which they are drawn. This is evident even in families where the disease is known to be the result of a new mutation. We can find no simple explanation for this effect, but it seems that new mutations in the dystrophin gene do not occur randomly in the population. The rate of new germline mutations in the dystrophin gene is particularly high, ${ }^{1}$ and the mechanisms by which these mutations occur are poorly understood. Further studies are needed to determine what aspects or covariates of deprivation may contribute to this effect and whether this ecological association occurs for other genes with a high level of new mutations.

Patients from deprived backgrounds have less access to health care than people from more affluent areas, ${ }^{3}{ }^{34}$ and diagnosis of Duchenne muscular dystrophy is often delayed. ${ }^{5}$ Children with Duchenne muscular dystrophy have a lifelong need for the highest quality of care, and the relatively high levels of deprivation associated with the disease may restrict availability of the sustained, high quality, specialised support needed.

Angela Hill provided much of the inspiration for this work. We thank Dr Louise Parker for helpful comments.

Contributors: $\mathrm{KB}$ oversaw the project and cowrote the paper. She is the guarantor. SR analysed the data. SO'D collected and processed the data.JGS contributed to developing the hypothesis and cowrote the paper.

Funding: The Newcastle Muscle Centre receives financial support from the Muscular Dystrophy Campaign.

Competing interests: None declared.

Gorospe JR, Hoffman EP. Duchenne muscular dystrophy. Curr Opin Rheumatol 1992;4:794-800.

2 Townsend P, Phillimore P, Beattie A. Health and deprivation: inequality and the north. London: Croom Helm, 1988

3 Benzeval M, Judge K. Access to healthcare in England: continuing inequalities in the distribution of general practitioners. J Pub Health Med 1996; 18:33-40.

4 Acheson D. Independent enquiry into inequalities in health. London: Stationery Office, 1998.

5 Bushby K, Hill A, Steele JG. Failure of early diagnosis in symptomatic Duchenne muscular dystrophy. Lancet 1999;353:557-8.

(Accepted 11 July 2001)

\section{Time out}

Until two years ago, I didn't really believe in sick leave. I could not imagine feeling so bad that I would be unable to make my body do whatever I wanted, or was scheduled, to do. And so, when I began to have fevers shortly after returning from Africa, I fitted my tropical PUO screen in around clinical commitments. The results were negative, so I stopped measuring my temperature and carried on.

Months passed, and I finally admitted that my symptoms weren't going away and made an appointment with the infectious disease team. More tests and nothing-we decided it was most likely to be physiological, and I went back into "head in the sand" mode.

A few more months, and I felt slowly worse. I developed a cough, and strange lumps came up in my axillas that I dealt with by not looking at them. One day I was due to be on call. Feeling unwell, I took my temperature $-39^{\circ} \mathrm{C}$. Convinced that a quick sleep would see me right, I rested and then went to work. My colleague, also a good friend, took one look at me and told me to go home again. I protested, but she was quietly insistent. Without her, I shudder to think what kind of mess I would have made of the evening. I was still in the mindset born of years of indoctrination that being there, come what may, was more important than being able to do the job properly.

Two days later I was admitted to hospital. Suddenly I had permission to take time out. There was no doubting my authenticity, and no one (not even me) could expect me to be at work. I lay there, sweating and hot, while diagnoses were tested and discarded. Cocooned in my illness, I did nothing and nothing was expected of me. Life at work went on with barely a hitch-I was, after all, entirely dispensable.
My fever broke, and my lucidity returned. The really nasty possibilities had been eliminated, but there was still no diagnosis. A virus, most likely. I returned to work. My symptoms now were now attributed to a postviral state in my head, and everyone knows that, with a bit of moral fibre, you can just get on with it.

I changed hospitals as part of my rotation and worked with an unusually empathetic consultant. He somehow made me feel that he knew I wasn't "someone who takes sick leave" but gave me permission to be someone who takes sick leave when it is needed.

The second time I was admitted I actually took myself. My fever soared again, and all the tests came back negative. Despite my negative autoantibody status, it was decided to give me a trial of corticosteroids. The effect was impressive. Back on my feet again, there was no arguing with the fact that I was no longer a healthy person and that I was going to have to give my health some priority in my life.

I am now (three years on) in remission from whatever it is and have been well, off the steroids, for almost six wonderful months. So what have I learned?

I now know how frightening it is to be a patient, and have first hand experience of several commonly requested investigations. I know why the nurses, sympathetic and bearing clean sheets, get all the chocolates. I know to treasure my health as one of my greatest assets, and I know that if I relapse then I can stop and take time out to recover and that the world will continue turning exactly the same as usual.

Sarah Smith specialist registrar in geriatrics and general medicine, Wycome Hospital (scsmith@doctors.org.uk) 